\title{
Blakiston's Fish-owl Bubo blakistoni and logging: Applying resource selection information to endangered species conservation in Russia
}

\author{
JONATHAN C. SLAGHT and SERGEI G. SURMACH
}

\section{Summary}

Blakiston's Fish-owl Bubo blakistoni is classified as 'Endangered' by IUCN; this species is associated with riparian old-growth forests in north-east Asia, a landscape threatened by a variety of impacts (e.g. logging, agricultural development, human settlement). We examined a $20,213 \mathrm{~km}^{2}$ study area in Primorye, Russia, and assessed the ability of the protected area network to conserve Blakiston's Fish-owls by analysing resource selection of radio-marked individuals. Based on resource selection functions, we predicted that 6o-65 Blakiston's fish-owl home ranges could occur within the study area. We found that the protected area network within our study area contained only $19 \%$ of optimal Blakiston's fish-owl habitat and contained only eight potential home ranges (five of these within a single protected area-Sikhote-Alin Biosphere Reserve). We also found that $43 \%$ of optimal Blakiston's Fish-owl habitat was within current logging leases; lands capable of supporting habitat equivalent to 24 home ranges. The remaining optimal habitat ( $38 \%)$ was on federal land and potentially contained 28-33 Blakiston's Fish-owl home ranges. The current protected area network, by itself, is not sufficient to conserve the species because relatively few home ranges are actually protected. Therefore, outside of protected areas, we recommend protecting specific locations within potential home ranges that likely contain suitable nest and foraging sites, maintaining integrity of riparian areas, modifying road construction methods, and closing old and unused logging roads to reduce anthropogenic disturbance to the owls and the landscape.

\section{Introduction}

Blakiston's Fish-owl Bubo blakistoni (hereafter, 'Fish-owl') is a globally 'Endangered' species that nests and hunts within riparian old-growth forests of north-east Asia (Pukinskii 1973, Takenaka 1998, Slaght and Surmach 2008, Slaght et al. 2013a). This is among the largest owls in the world and one of the most poorly known of the Strigidae (Pukinskii 1973, Surmach 1998, Yamamoto 1999, Slaght and Surmach 2008). In the Russian Far East, Fish-owls are threatened by poaching, habitat degradation from logging, and overfishing (Mikhailov and Shibnev 1998, Surmach 1998, Slaght and Surmach 2008). Old-growth riparian forests have survived in this region because of Sovietera restrictions on tree harvest within a $5 \mathrm{~km}$ riparian buffer zone (Surmach 1998). Since the collapse of the Soviet Union, logging restrictions were greatly weakened and regulatory oversight has been poor (Newell 2004, Lesniewska et al. 2008). These changes have led to an expansion of logging with a concomitant increase in logging roads. Much of the Russian Far East is uninhabited, thus, placement of logging roads largely dictates access by humans to wilderness areas, which in turn results in both legal and illegal use of forests and their resources such as fish and wildlife (Clark and Gibbons 1991, Furniss et al. 1991). In the southern Russian Far East, roads are constructed along rivers to access tree harvest units (Slaght 2005), and a variety of loopholes is exploited to remove 
commercially valuable species from the forest legally and in great quantity (Newell and Wilson 1996). For example, "sanitation harvests", which ostensibly keep a forest free of fire-prone clutter and diseased trees, can be used as a legal mechanism to remove Korean pine Pinus koraiensis (CITES Appendix III) and other riparian tree species (especially Manchurian ash Fraxinus mandshurica) during the sanitation harvest process. In fact, Kovalev et al. (2011) suggested than 90-95\% of sanitation harvests in the region are resulting in the removal of healthy, valuable timber and not culling the dead or damaged trees that the law allows. Additionally, illegal logging is rampant in the area (Vandergert and Newell 2003).

In Russia, mortality of Fish-owls likely increases wherever they come into contact with humans. For example, these birds drown when accidentally caught in fishing nets, freeze in winter when trapped in snares set for fur-bearing mammals, and are either wantonly shot or specifically targeted for fear they will ruin the pelts of fur-bearing species (Spangenberg 1965, Dykhan and Kisleiko 1988, Mikhailov and Shibnev 1998, Slaght and Surmach 2008, Andreev 2009). Of 26 recorded mortalities (Pukinskii 1993, Surmach 1998, Yelsukov 2005, Andreev 2009, Slaght and Surmach unpubl. data) all but two were human-caused deaths. Collisions with vehicles are another source of Fish-owl mortality in both Russia (Slaght and Surmach unpubl. data) and Japan (Yanagawa 1993, Saito 2002).

In addition to Fish-owl deaths caused by vehicles (three Fish-owls were killed by collisions in our study area from 2010 to 2013, including a female in 2012 that we had banded and monitored since 2007), logging roads themselves have indirect impacts on Fish-owls. First, large, riparian old-growth tree species such as Japanese poplar Populus maximowiczii and chosenia Chosenia arbutifolia, which are favored by Fish-owls as nest trees (Dykhan and Kisleiko 1988, Takenaka 1998, Andreev 2009, Slaght et al. 2013a), are sometimes used by logging companies for bridge construction (Slaght and Surmach 2008). A nest tree in our study area near the Maksimovka River was felled for this purpose. Second, roads built near waterways increase water temperature and siltation, which degrades habitat for the owl's salmonid prey (Chamberlain et al. 1991, Hunter and Schmiegelow 2010).

Threats to Fish-owl conservation are exacerbated because there is no specific conservation plan for this species in Russia, despite Fish-owls having international, federal, and regional protected status. Indeed, the few studies conducted on Fish-owls in Russia do not have sufficient scientific or statistical rigour to guide conservation and management recommendations (Slaght and Surmach 2008).

Therefore, our objectives were to assess the potential of current protected areas within our study area in Primorye, Russia to conserve Fish-owl populations and to develop recommendations for Fish-owl conservation and management in areas not currently under conservation protection. Our intent was not to recommend exclusion of either logging or other resource extraction from areas used by Fish-owls, but rather to encourage multiple uses of these forests in an informed, sustainable way.

\section{Methods}

\section{Study area}

Our $20,213 \mathrm{~km}^{2}$ study area bordered the Sea of Japan in Primorye, Russia (Figure 1a). The area was primarily forested ( $88 \% ; 51 \%$ deciduous and $37 \%$ coniferous) and mountainous, with slopes bisected by nine major rivers (described here from south to north: Avvakumovka, Zerkalnaya, Rudnaya, Dzhigitovka, Serebryanka, Taezhnaya, Kema, Amgu, Maksimovka) that flow into the Sea of Japan. Following a century of anthropogenically caused fire and highgrading tree harvest practices (which selectively removes the highest quality trees from the forest and over time results in poor-quality forest), many of the original mixed Korean pine/ deciduous forests, particularly in the southern portions of the study area, were converted to second-growth forests dominated by Mongolian oak Quercus mongolica and Japanese white birch Betula platyphylla (Newell and Wilson 1996, Miquelle et al. 1999). River valleys typically contain high vegetation diversity, with tree species such as Japanese poplar, chosenia, 


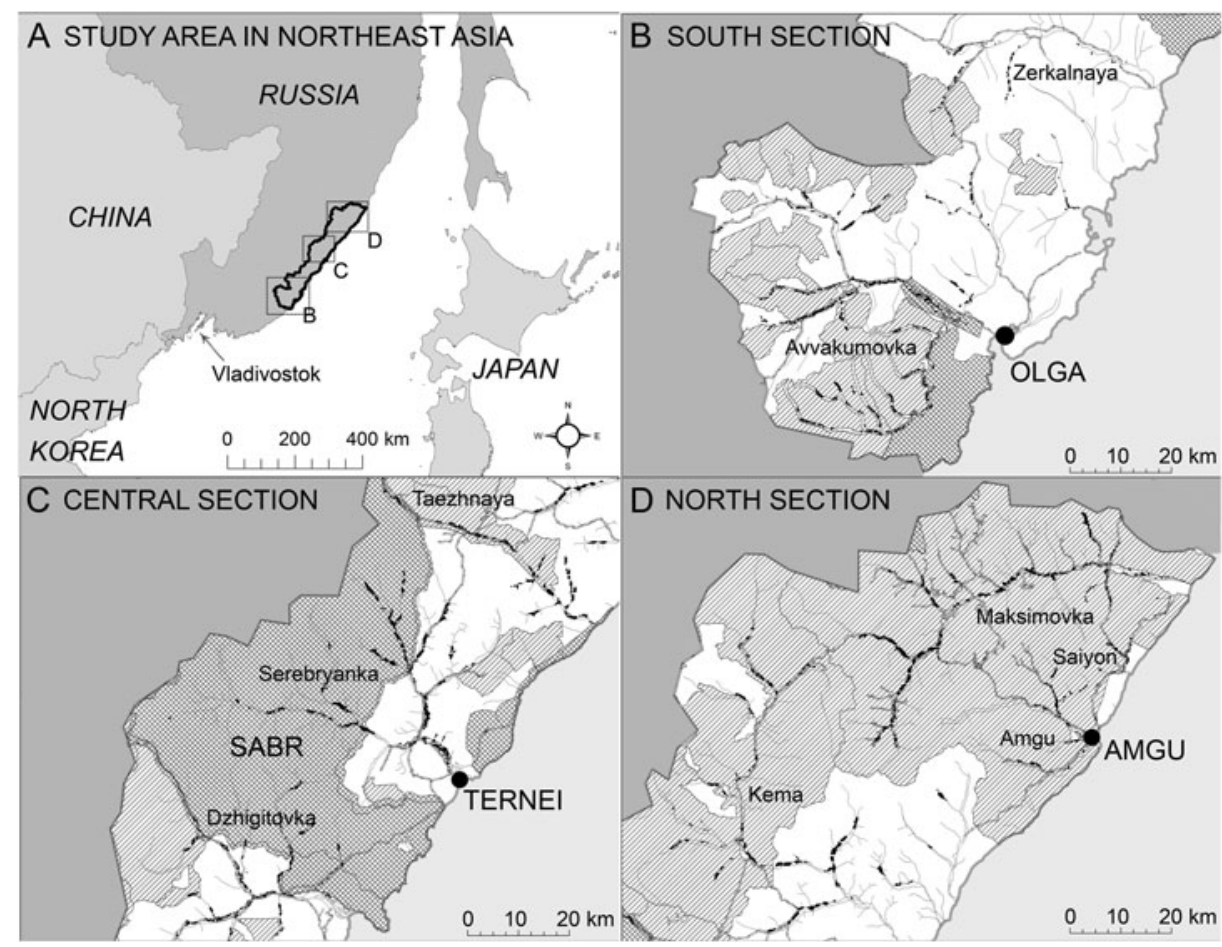

Figure 1. Map of study area in Primorye, Russia, showing locations of optimal Blakiston's Fish-owl habitat (black polygons), protected areas (cross-hatching), lands leased for logging (hatching), federal lands (white), major river drainages, the Sikhote-Alin Biosphere Reserve (SABR), and some human settlements (Olga, Ternei, Amgu) for reference. "Optimal habitat" is defined biologically as the areas most likely to contain the resources associated with Fish-owl breeding and hunting, and statistically as the area within the top $2 \%$ predicted probability-of-use.

Korean pine, Manchurian ash, Japanese elm Ulmus propinqua, and Asian birch Betula costata common in forests.

During our study, approximately $38 \%$ of the study area $\left(7,815 \mathrm{~km}^{2}\right)$ was leased by the provincial government to private logging companies, and $18 \%\left(3,839 \mathrm{~km}^{2}\right)$ was protected by federal or provincial statues (Figure $\mathrm{Ib}-\mathrm{d}$ ). In practice, few protected areas received conservation enforcement (Newell 2004). One of the exceptions was the Sikhote-Alin Biosphere Reserve (or "zapodernik"), of which $58 \%\left(2,355 \mathrm{~km}^{2}\right.$ of $4,011 \mathrm{~km}^{2}$ in total) was found within our study area (Figure $1 \mathrm{c}$ ). A zapovednik is a federally-protected area with the key distinction that human use is largely limited to scientific research and patrols by inspection staff: use by the public for any purpose (e.g. recreation, resource extraction) is illegal as a rule. The human population in the study area was $\sim 100,000$ residents; most of whom lived in small cities in the south (Dalnegorsk $\sim 40,000$ inhabitants; Kavalerovo $\sim 30,000$ inhabitants). The remaining settlements were small, typically having 500-5,000 residents.

\section{Owl monitoring}

We collected GPS data from seven resident adult Fish-owls on five territories in three river drainages (Amgu: $n=4$ birds [2 pairs], Serebryanka: $n=2$ [ 1 pair], Saiyon: $n=1$ male; Figure 1). Owls were fitted with GPS dataloggers (40 $\mathrm{g}$ and $90 \mathrm{~g}$ models, Sirtrack Tracking Solutions, Havelock North, 
New Zealand), which were attached as backpacks using $1.10 \mathrm{~cm}$ Teflon-coated ribbon (Bally Ribbon Mills, Pennsylvania, USA) following recommendations by Kenward (2001). We collected global positioning system (GPS) data from 2008 to 2010, but only used data from 2009 to 2010 to create the predictive model (we used data from 2008 to assess model fit). Mean number of GPS locations per Fish-owl was $271 \pm 74$ (mean \pm SE, range 52-536 locations). We did not detect any negative impacts on Fish-owls from our GPS devices; all pairs successfully bred and fledged chicks during the data collection process.

\section{Estimating probability-of-use by Fish-owls}

We estimated probability-of-use by Fish-owls for the study area using selection coefficients derived from a previous analysis of resource selection in the southern Russian Far East (see Slaght et al. 2013 b for details). Briefly, Slaght et al. $2013 \mathrm{~b}$ assessed resource selection exhibited by GPS datalogger-marked Fish-owls using the synoptic model of space use, a method that integrates home range size and resource selection within an information-theoretic framework (Horne et al. 2008). The synoptic model is well-suited to describe space use by an animal (i.e. the Fish-owl) that uses habitat linearly (i.e. a river valley; Slaght et al. 2013b).

Slaght et al. (2013b) identified four covariates (Fish-owl presumptive resources) with sufficient statistical support to predict Fish-owl resource use: topography (higher probability of use in river valleys), distance to water (higher probability of use closer to waterways), distance to permanently open water patches (higher probability of use closer to water patches that remain unfrozen year-round), and the number of river channels (higher probability of use in locations with greater channel complexity). The resultant parameter estimates for these covariates formed the basis of our comparisons here of use versus availability to predict Fish-owl probability-of-use across the study area. We compared 1,895 used sites (Fish-owl locations) with 505,375 available sites (a grid of points spaced evenly at $200 \mathrm{~m}$ intervals across our $20,213 \mathrm{~km}^{2}$ study area).

We estimated mean selection coefficient values for topography, distance to water, distance to permanently open water patches, and number of river channels along with their associated standard errors, by averaging the selection coefficients from each Fish-owl following methods adapted from Biggerstaff and Tweedie (1997) using the DerSimonian and Laird (1986) methodof-moments estimator. We standardised each selection coefficient using:

$$
H_{j}^{*}\left(x_{i}\right)=\frac{\left[H_{j}\left(x_{i}\right)-H_{j}(\min )\right]}{\left[H_{j}(\max )-H_{j}(\min )\right]}
$$

where $H_{j}\left(x_{i}\right)$ was the unstandardised value of each covariate $j$ at grid cell $\left(x_{i}\right)$, and $H_{j}(\min )$ and $H_{j}(\max )$ was the minimum and maximum values from the unstandardised covariate, respectively. We then assigned these standardised values to each of the 505,375 cells across the study area. The relative probability of use by a Fish-owl at a given grid cell $\left(x_{i}\right)$ was defined as:

$$
\operatorname{Pr}\left(x_{i}\right)=\frac{\operatorname{Exp}\left(\bar{\beta}_{1} H_{1}^{*}\left(x_{i}\right)+\bar{\beta}_{2} H_{2}^{*}\left(x_{i}\right)+\bar{\beta}_{3} H_{3}^{*}\left(x_{i}\right) \ldots\right)}{\sum_{i=1}^{M} \operatorname{Exp}\left(\bar{\beta}_{1} H_{1}^{*}\left(x_{i}\right)+\bar{\beta}_{2} H_{2}^{*}\left(x_{i}\right)+\bar{\beta}_{3} H_{3}^{*}\left(x_{i}\right) \ldots\right)} .
$$

where $\operatorname{Pr}\left(x_{\mathrm{i}}\right)$ was the probability of finding a Fish-owl in a particular grid cell, and $\bar{\beta}_{j}$ was the mean selection coefficient of variable $j$. The denominator was simply the numerator summed over the study area grid.

\section{Model assessment}

We assessed model fit of the final probability-of-use map following empirical methods similar to those outlined by Durner et al. (2009), in which we divided the study area into units of equal size 
(in our case, 50 units) using the range of probability-of-use values. Thus, we designated the area having the top $2 \%$ of predicted cumulative probability-of-use values as category " 50 ", the next $2 \%$ of predicted use values designated area as category " 49 " and so forth until the last category was " $I$ ", which was the area with the lowest $2 \%$ cumulative probability-of-use (Figure 2 ). We then assigned each Fish-owl GPS location to one of these categories. We expected that Fish-owl locations would follow an exponential distribution if model fit was good, because probability of resource use is proportional to the exponential linear function of the covariates (Manly et al. 2002, Durner et al. 2009). We assessed model prediction by plotting Fish-owl GPS locations $(n=275)$ that were not used to build the predictive model onto a map that predicted probability-ofuse based on the original location data. If model prediction was good, we similarly expected that these locations would follow an exponential distribution. We also assessed model fit by plotting 16 locations of Fish-owl "sign" from areas outside our sample population (i.e. from owls that were not marked with GPS dataloggers) from across the study area, and compared those locations to the predicted probability of use. We defined "sign" as nest locations $(n=I I)$, visual detections $(n=4)$, or tracks (Fish-owls often walk along river banks; $n=1$ ).

Fish-owls show strong patterns of resource selection at multiple spatial scales (Slaght et al. $2013 b)$. These patterns were identified by consistent presence of resources that formed the core of a Fish-owl's home range. We defined this suite of resources as representing "optimal habitat", using both biological and statistical criteria. Biologically, optimal habitat was the area most likely to contain the resources associated with Fish-owl breeding and hunting (nest trees and foraging sites, see Slaght et al. 2013a). Statistically, optimal habitat was the area within the top $2 \%$ predicted probability of use (category " $5 \mathrm{O}^{\prime}$, cumulative probability $\leq 0.24511$, see Model fit below

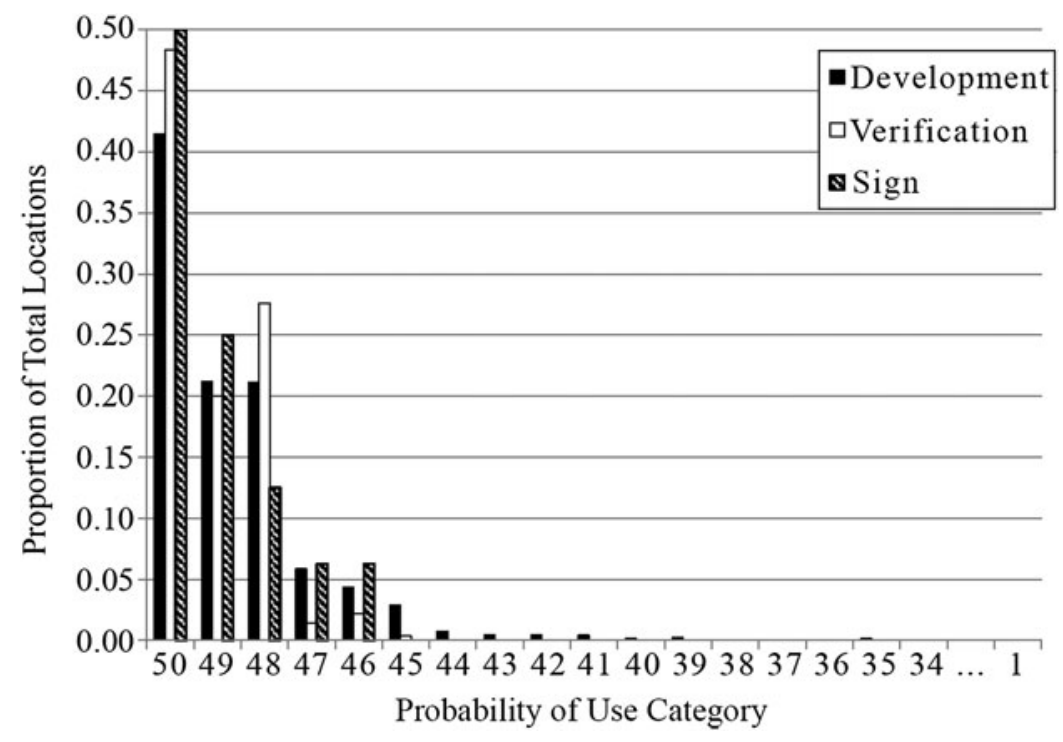

Figure 2. Histogram of Blakiston's Fish-owl locations used to develop model prediction (black bars, $n=1,895$ ). Two sources to verify model prediction are also shown: GPS locations not used to develop model (open bars, $n=275$ ), and Fish-owl sign (hatched bars, $n=16$ ). All are grouped to show proportion of observations by equal-area probability of use categories, where " 50 " contains the highest $2 \%$ probability of use, and " $I$ " contains the lowest $2 \%$ probability of use. The largest proportions of development data (41\%), GPS verification data $(48 \%)$, and sign verification data $(50 \%)$ fell within the top $2 \%$ of probability-of-use bin (cumulative probabilities from 0.00000 to 0.24511 ). The negative exponential distributions indicate good model fit. 
for justification). Using this statistical delineation of optimal habitat and the mean linear length of a Fish-owl home range (12.4 km; Slaght et al. 2013 b), we estimated its distribution in the study area and then used this distribution to estimate the potential number of Fish-owl home ranges within the study area.

\section{Results}

\section{Model fit}

The frequency distributions of Fish-owl locations followed the exponential function, which suggested that the covariates derived in Slaght et al. (2013b) accurately identified Fish-owl resource selection across the study area (Figure 2). Histograms of Fish-owl locations showed that $41 \%$ of all locations fell within the top $(2 \%)$ probability-of-use category (cumulative probabilities $\leq 0.24511$ ). We used the lower end of this range of values (0.24511) as an arbitrary cut-off to identify the distribution of optimal habitat. The frequency distributions of Fish-owl GPS locations used for model verification also followed an exponential function, as did the 16 locations of independent Fish-owl sign, which suggested that the model had strong predictive power (Figure 2).

\section{Predicted distribution of optimal Fish-owl habitat}

Resource selection functions predicted $216.24 \mathrm{~km}^{2}$ of optimal habitat (areas with $\leq 0.24511$ cumulative probability of use), which represents only $1 \%$ of the study area, distributed across the study area in all major river drainages (Figure 1 ). Approximately $38 \%$ of optimal habitat $\left(82.68 \mathrm{~km}^{2}\right)$ was outside the boundaries of protected areas and logging leases, and $43 \%$ of optimal habitat $\left(92.80 \mathrm{~km}^{2}\right)$ fell within logging leases. Only $19 \%$ of optimal habitat $\left(40.76 \mathrm{~km}^{2}\right)$ was within current or proposed protected areas.

Based on probability-of-use distribution and maximum linear home range distances (Slaght et al. 2013 b), we estimated 6o-65 Fish-owl home range areas could potentially be within the study area. The Avvakumovka and Serebryanka River drainages contained the greatest number of potential Fish-owl home range areas (12 each), followed by the Kema (10), Maksimovka (10), Dzhigitovka (7), Amgu (5), and Taezhnaya (4) drainages (Figure I). All of these drainages (except the Avvakumovka) were within Ternei County. The remaining drainages, mostly minor, potentially supported one or two home range areas each to sum approximately five additional potential home range areas.

\section{Discussion}

\section{Model inference}

Our assessment of model fit demonstrates that the parameter estimates describing individual Fish-owl resource use from Slaght et al. (2013b) can be used to predict optimal habitat for Fishowls across our entire study area, and can be used as a starting point to identify priority areas for conservation. However, the method as applied to this larger area was not without shortcomings. For example, Slaght et al. (2013a) indicated that old growth riparian forest was important both for Fish-owl nesting and foraging, but this key resource was not one of the four covariates with sufficient statistical support from Slaght et al. (2013b) to be considered here. Slaght (2011) speculated that this covariate's omission might have occurred because Fish-owls were sometimes nesting in "remnant trees and snags" in disturbed forest and individual habitat features like snags could not be identified using available (10-m resolution) satellite imagery (i.e. this resource element occurred at too fine a scale to be estimated).

Because of likely subsequent misclassifications in the predictive model, we suggest that all areas that are identified as optimal habitat for Fish-owls should be scrutinised before they are incorporated as part of a management plan. Specifically, all presumed optimal habitat should be surveyed 
for the presence of large trees $(\geq \sim 80 \mathrm{~cm} \mathrm{dbh})$ and nearby suitable foraging habitat (see Slaght $e t$ al. 2013a) to confirm suitability for protected area designation.

\section{Protected area designation}

Our estimate of 6o-65 potential Fish-owl home range areas within the total study area was similar to that proposed by Surmach (1998; 50-70 breeding pairs) based on both his extensive natural history observations and informational surveys of hunters. Given dispersion and amount of optimal Fish-owl habitat within areas currently receiving conservation protection, we estimated these protected areas could sustain approximately eight Fish-owl home range areas, five of which are within a single protected area (Sikhote-Alin Biosphere Reserve; Serebryanka and Dzhigitovka River drainages; see Figure $\mathrm{IC}$ ). Within logging leases, there was sufficient optimal habitat for $\sim 24$ Fish-owl potential home range areas. It is clear from the dispersion of optimal Fish-owl habitat across the study area that existing protected areas alone are not sufficient to conserve Fish-owl populations on the eastern slope of the Sikhote-Alin Mountains. Should no further steps be taken to protect Fish-owls, and resource extraction continuing apace, the population in the study area might eventually contract to a single protected area with only enough habitat for approximately five pairs. Therefore, additional management actions are necessary to conserve the owls.

Although all optimal habitat (as defined above) is contained within the borders of 'water protection zones'-legal mechanisms of the Forest Code of the Russian Federation to maintain proper ecosystem function and to protect spawning grounds of commercially-valuable salmonids (Shestakov 2003) - this law does little to protect Fish-owls or their habitat. This is because the only legallyprohibited activities within water protection zones are clear felling of forests and chemical application, and even these restrictions are not absolute (Russian Federal Forest Service 2006). Therefore, timely alternative conservation strategies need to be developed, including agreements with logging lease holders to integrate existing law with sustainable use and management of resources important to Fish-owls.

One attractive management possibility that would incorporate knowledge of Fish-owl resource selection with their conservation is the designation of the "specially-protected forest patch", described here using the transliterated Russian acronym OZUL ('Osobo Zashchitnii Uchastok Lesa'; Kovalev 2014). These micro-protected areas are designed to conserve specific habitat patches on government land leases while otherwise allowing resource extraction to occur (Shubin 1993). OZULs vary in size depending on conservation need and are actions that can be implemented by the leaseholder. Examples of existing OZULs include $300 \mathrm{~m}$ radius areas around Blackbilled Capercaillie Tetrao parvirostris leks, and $100 \mathrm{~m}$ strips along rivers in Eurasian beaver Castor fiber habitat (Russian Federal Forest Service 1993).

A network of OZULs has the potential to be a keystone property of a Fish-owl conservation plan (if combined with existing riparian conservation measures and additional recommendations on logging road construction and maintenance-see next section) because OZULs would protect existing or potential nesting sites and foraging sites. A Fish-owl OZUL should have at least a $\sim 150 \mathrm{~m}$ radius protected area around a nest tree or foraging site to minimise human disturbance (Fish-owls are highly intolerant of humans and often flush when approached within 100-150 m; Nechaev 1969; Slaght pers. obs.).

Although clear felling is prohibited in an OZUL, the selective removal of dead or damaged trees is permissible by existing legislation (Article 17, Forest Code of the Russian Federation 2006), and a recent proposal designed to set standards for OZUL creation implicitly allows for such sanitation cuts (Kovalev 2014). However, such a concession would be inappropriate within Fish-owl OZULs because dead and dying trees-often the targets of sanitation cuts-are either characteristic of old-growth forest or are used as nest sites by the owls (see Slaght et al. 2013a). Thus, a ban on snag or damaged tree harvest within a Fish-owl OZUL should be imposed, specifically for Japanese poplar, chosenia, and elm that are $\geq 80 \mathrm{~cm}$ dbh because these large trees are the most likely to be suitable Fish-owl nest trees (Slaght et al. 2013a). 
Optimal habitat (as we delineated it) can act as a principal guide for OZUL placement, thereby protecting key habitat components within Fish-owl home ranges. Once a logging leaseholder agrees to allow creation of Fish-owl OZULs, biologists should survey optimal habitat as identified in Figure 1 . The purpose of such surveys would be to confirm presence of key habitat characteristics (number of potential nest trees, availability of foraging locations; see Slaght et al. 2013a). Each patch of optimal habitat (either nesting or foraging habitat) would then be ranked by its suitability to meet these habitat needs (i.e. First Category OZUL, Second Category OZUL; see Slaght 2011 for specifics).

As Fish-owls readily nest in artificial nest boxes when natural cavities are absent (Yamamoto 1999, Berzan 2003), this flexibility should be exploited by installing nest boxes in OZULs of known home ranges. This will ensure continuous nesting opportunities for a resident pair should a favoured tree become unsuitable (given that existing nest trees are vulnerable to destruction by storms owing to their size and age). However, using nest boxes does not mitigate loss of other habitat elements (resources) as we have defined them, so nest boxes in most cases are only a stopgap measure to enhance a site that is lacking only this key element.

Although optimal habitat represents the area where important owl activities are centered (or could be centered), but it does not represent total habitat necessary for a home range. Fish-owl home ranges include multiple 'islands' of optimal habitat, and Fish-owls show substantial plasticity in habitat use within river valleys. Therefore, we stress that OZULs would form only part of a management plan with a goal to maintain healthy riparian ecosystems within river drainages.

\section{Recommendations for developing and maintaining logging roads}

Logging roads have a particularly high potential to impact Fish-owls because they are often in the same areas used by Fish-owls: river valleys, areas near water, and rivers with multiple channels. Roads should be constructed as far from water as feasible (and with a riparian buffer of at least $100 \mathrm{~m}$ between the road and the river) because roads that eliminate or degrade riparian buffers reduce the recruitment of large woody debris to waterways (Hunter and Schmiegelow 2010). Large woody debris may be particularly important for Fish-owls, which appear to prefer foraging in streams near riparian old-growth (the primary source of large woody debris; Slaght et al. 2013a), perhaps related to the greater suitability of these river stretches for juvenile salmonids.

Where stream crossings are unavoidable, bridges (not culverts) should be used as they are less likely to impede salmonid migration (Furniss et al. 1991). Bridge constructors should avoid felling live Japanese poplar, chosenia, and elm $\geq 50 \mathrm{~cm}$ dbh or snags of these species $\geq 80 \mathrm{~cm}$ to use as bridge supports because large specimens of these tree species are either existing Fish-owl nest trees or candidate nest trees (Slaght et al. 2013a). Other tree species (Dahurian larch Larix gmelinii, aspen Populus tremula, and others) are often common in these areas and their removal for bridge construction would likely not have a detrimental effect on Fish-owls.

Road location within a forested landscape dictates where human use is concentrated, and regardless of initial purpose, recreational activity in an area increases dramatically after road construction (Clark and Gibbons 1991). For Fish-owls it is critical that forest roads facilitating human access to waterways be closed following use, as such actions may lead to reduced Fishowl mortality. Just as known Fish-owl nest trees should be a priority for OZUL designation, unused logging roads near nest trees should be a priority for closure. Roads can be closed by erecting barricades such as deep trenches, boulders, or gates, and these closures minimise road maintenance and reopening costs should logging activities resume at a later date (Oregon Department of Forestry 2000). We recommend that in areas with high probability-of-use by Fish-owls and within logging leases, road closures should be a high priority following cessation of logging activities.

Considerable optimal Fish-owl habitat within the Amgu, Kema, and Maksimovka River drainages is within logging leases controlled by one organization, TerneiLes, which is among the 
largest timber companies in the Russian Far East (Newell 2004). In fact, if all Fish-owl habitat under the purview of this one company was given OZUL consideration and designation, $\sim 20$ additional potential Fish-owl territories would be protected (thus tripling the number of home range areas currently protected, and protecting nearly half of all potential home ranges in our $20,213 \mathrm{~km}^{2}$ study area). TerneiLes has attained Forest Stewardship Council (FSC) certification, and has previously solicited recommendations from conservation organisations and biologists for placement of OZULs within its leases. Thus, engagement is realistic and could feasibly contribute significantly to Fish-owl conservation in the region.

\section{Acknowledgements}

We thank S. Avdeyuk, A. Katkov, R. Kozhichev, N. Gorlach, E. Pimenova, A. Popov, M. Pogiba, A. Ryzhov, and A. Yanchenko and for their help with data collection in the field. We also thank volunteers A. Balanov, J. Goodrich, M. Miquelle, A. Mukhachova, I. Seryodkin, and S. Soutyrina. V. and A. Volkov provided logistical support in the field. R.J. Gutiérrez was instrumental in structuring and editing this manuscript. J. Horne provided immeasurable support and advice regarding the synoptic model. T. Arnold, M. Bauer, and D. Miquelle provided considerable and constructive input on an earlier draft, while P. Zahler and B. Milakovsky offered advice on a later version. D. Tempel, L. Berkeley, C. Phillips, and M. Kouffeld-Hansen provided intellectual stimulation. S. Soutyrina, Y. Petrunenko, R. Kozhichev, and T. Takenaka provided additional Fish-owl locations for model verification. We acknowledge financial and logistical support from the Wildlife Conservation Society Russia Program, and financial support for fieldwork from the Amur-Ussuri Centre for Avian Biodiversity, the United States Department of Agriculture Forest Service (grants o6-DG-11132726-215, 07-DG-11132792-153), Disney Worldwide Conservation Fund, National Birds of Prey Trust, Bell Museum of Natural History, Columbus Zoo, Denver Zoo, Minnesota Zoo, and National Aviary. JCS was substantially supported by the University of Minnesota non-sponsored account to R. J. Gutiérrez, the Minnesota Agriculture Experiment Station, University of Minnesota Doctoral Dissertation Fellowship, the Gordon Gullion Scholarship, and the Leigh H. Perkins Fellowship.

\section{References}

Andreev, A. V. (2009) The Blakiston's fish owl (Ketupa blakistoni) at north-eastern limits of is range. Osnabr. Naturwiss. Mitt. 35: 47-54.

Berzan, A. P. (2003) Notes on observations of Blakiston's fish owl on Kunashir Island and experiments with artificial nest sites Tyto 8: $21-35$.

Biggerstaff, B. J. and Tweedie, R. L. (1997) Incorporating variability in estimates of heterogeneity in the random effects model in meta-analysis. Stat. Med. 16: 753-768.

Chamberlain, T. W., Harr, R. D. and Everest, F. H. (1991) Timber harvesting, silviculture, and watershed processes. Pp. 181-204 in W. R. Meehan, ed. Influences of forest and rangeland management on salmonid fishes and their habitats. Bethesda, USA: American Fisheries Society. Special Publication 19.
Clark, R. N. and Gibbons, D. R. (1991) Recreation. Pp. 459-482 in W. R. Meehan, ed. Influences of forest and rangeland management on salmonid fishes and their habitats. Bethesda, USA: American Fisheries Society. Special Publication 19.

DerSimonian, R. and Laird, N. M. (1986) Meta-analysis in clinical trials. Control. Clin. Trials 7: 177-188.

Durner, G. M., Douglas, D. C., Nielson, R. M., Amstrup, S. C., McDonald, T. L., Stirling, I., Mauritzen, M., Born, E. W., Wiig, O., DeWeaver, E., Serreze, M. C., Belikov, S. E., Holland, M. M., Maslanik, J., Aars, J., Bailey, D. A. and Derocher, A. E. (2009) Predicting 21st-century polar bear habitat distribution from global climate models. Ecol. Monogr. 79: 25-58.

Dykhan, M. B. and Kisleiko, A. A. (1988) Number and distribution of Blakiston's fish 
owls on Kunashir Island during the breeding period. Pp. 29-32 in N. M. Litvinenko, ed. Rare birds of the Russian Far East and their protection. Vladivostok, Russia: Dalnevostochnoe Otdeleniye Akademii Nauk SSSR. (In Russian with English abstract).

Furniss, M. J., Roelofs, T. D. and Yee, C. S. (1991) Road construction and maintenance. Pp. 297-324 in W. R. Meehan, ed. Influences of forest and rangeland management on salmonid fishes and their habitats. Bethesda, USA: American Fisheries Society. Special Publication 19.

Horne, J. S., Garton, E. O. and Rachlow, J. L. (2008) A synoptic model of animal space use: simultaneous estimation of home range, habitat selection, and inter/intraspecific relationships. Ecol. Modell. 214: 338-348.

Hunter, M. L. and Schmiegelow, F (2010) Wildife, forests, and forestry: Principles of managing forests for biological diversity. Second edition. Englewood Cliffs, USA: Prentice-Hall.

Kenward, R. E. (200I) A manual for wildlife radio tagging. New York, USA: Academic Press.

Kovalev, A. P., ed. (2014) [Guidelines for the establishment of specially-protected forest patches to conserve habitat of rare and commercially-valuable plant and animal species in the southern Russian Far East]. Khabarovsk, Russia: Ministry of Natural Resources and Ecology of the Russian Federation, Far Eastern Forestry Research Institute. (In Russian).

Kovalev, A. P., Ryabukhin, P. B, Kovalev, V. A. and Alexeenko, A. Y. (2011) [On the necessity of transition to sustainable forest management in the Russian Far East]. Bull. Tikh. Gos. Uni. 2: 61-71. (In Russian).

Lesniewska, F., Laletin, A., Lebedev, A. and Harris, K., eds. (2008) Transition in the taiga: the Russian forest code 2006 and its implementation process. Helsinki, Finland: Taiga Rescue Network, Finnish Association for Nature Conservation.

Manly, B. F. J., McDonald, L. L., Thomas, D. L., McDonald, T. L. and Erickson, W. P. (2002) Resource selection by animals: statistical design and analysis for field studies. Boston, USA: Kluwer Academic Press.
Mikhailov, K. E. and Shibnev, Y. B. (1998) The threatened and near-threatened birds of northern Ussuriland, south-east Russia, and the role of the Bikin River basin in their conservation. Bird Conserv. Internatn. 8: 141-171.

Miquelle, D. G., Merrill, T. W., Dunishenko, Y. M., Smirnov, E. N., Quigley, H. B., Pikunov, D. G. and Hornocker, M. G. (1999) A habitat protection plan for the Amur tiger: developing political and ecological criteria for a viable and-use plan. Pp. 273-295 in J. Seidensticker, S. Christie and P. Jackson, eds. Riding the tiger: Tiger conservation in humandominated landscapes. Cambridge, UK: Cambridge University Press.

Nechaev, V. A. (1969) [Birds of the southern Kuril Islands]. Leningrad, Soviet Union: Nauka. (In Russian).

Newell, J. (2004) The Russian Far East: a reference guide for conservation and development. McKinleyville, USA: Daniel and Daniel Publishers.

Newell, J. and Wilson, E. (1996) The Russian Far East: Forests, biodiversity hotspots, and industrial developments. Tokyo, Japan: Friends of the Earth.

Oregon Department of Forestry (2000) Forest roads manual. Salem, USA: Oregon Department of Forestry.

Pukinskii, Y. B. (1973) Ecology of Blakiston's fish owl in the Bikin river basin. Byull. Mosk. O-va Ispyt. Prir. Otd. Biol. 78: 40-47. (In Russian, with English abstract).

Pukinskii, Y. B. (1993) Blakiston's fish owl Ketupa blakistoni. Pp. 290-302 in V. D. Ilichev, ed. [Birds of Russia and adjacent regions]. Moscow, Russia: Nauka. (In Russian).

Russian Federal Forest Service (1993) [Rules on forest felling in the lowlands of European Russia]. Order 226. (In Russian).

Russian Federal Forest Service (2006) [Forest Code of the Russian Federation]. N 200-F3. (In Russian).

Saito, K. (2002) Diseases and mortality of the Blakiston's Fish Owl (Ketupa blakistoni), with special reference to traffic accidents and their prevention. Pp. 36-38 in F. T. Scullion and T. A. Bailey, eds. Proceedings of the World Association of Wildlife Veterinarians Wildlife Sessions at the 27th World Veterinary Conference. Tunis, Tunisia. 
Shestakov, A. S., ed. (2003) Protected areas in Russia: Legal regulation. An overview of federal laws. Moscow, Russia: KMK Scientific Press, Ltd.

Shubin, V. A. (1993) [Approved measures for the creation of specially-protected forest patches]. Forest Service of the Russian Federation, Order 348. (In Russian).

Slaght, J. C. (2005) Influence of selective logging on avian denisty, abundance, and diversity in Korean pine forests of the Russian Far East. M.S. Thesis, University of Minnesota, Saint Paul, USA.

Slaght, J. C. and Surmach, S. G. (2008) Biology and conservation of Blakiston's fish owls in Russia: a review of the primary literature and assessment of the secondary literature. J. Raptor Res. 42: 29-37.

Slaght, J. C., Surmach, S. G. and Gutiérrez, R. J. (2013a) Riparian old-growth forests provide critical nesting and foraging habitat For Blakiston's Fish Owl Bubo blakistoni in Russia. Oryx 47: 553-56o.

Slaght, J. C., Horne, J., Surmach, S. G. and Gutiérrez, R. J. (2013b) Home range and resource selection by animals constrained by linear habitat features: an example of Blakiston's Fish Owl. J. Appl. Ecol. 50: 1350-1357.
Spangenberg, Y. P. (1965) [Birds of the Iman River basin]. Sb. Tr. Zool. Museya MGU 9: 98-202. (In Russian).

Surmach, S. G. (1998) Present status of Blakiston's fish owl (Ketupa blakistoni Seebohm) in Ussuriland and some recommendations for protection of the species. Rep. Pro Natura Found. 7: 109-123.

Takenaka, T. (1998) Distribution, habitat environments, and reasons for reduction of the endangered Blakiston's fish owl in Hokkaido, Japan. Ph.D. dissertation, Hokkaido University, Sapporo, Japan.

Vandergert, P. and Newell, J. (2003) Illegal logging in the Russian Far East and Siberia. Int. Forest Rev. 5: 303-306.

Yanagawa, H. (1993) Causes of wild bird mortality in eastern Hokkaido. Strix 12: $161-169$.

Yamamoto, S. (1999) [The Blakiston's Fish Owl]. Sapporo, Japan: Hokkaido Shimbun Press. (In Japanese).

Yelsukov, S. V. (2005) Owls of north-east Primorye. Pp. 429-437 in S. V. Volkov, V. V. Morozov and A. V. Sharikov, eds. Owls of northern Eurasia. Moscow, Russia: Working Group of Birds of Prey and Owls, Institute of Ecology and Evolution, Russian Academy of Sciences. (In Russian with English abstract).

\section{JONATHAN C. SLAGHT* \\ Department of Fisheries, Wildlife, and Conservation Biology, University Of Minnesota, 200 Hodson Hall, 1980 Folwell Avenue, Saint Paul, MN, USA, 55108. \\ Present address: Wildlife Conservation Society, Russia Program, 17a Aleutskaya St. Apt.31, Vladivostok, Russia, 690090. \\ SERGEI G. SURMACH \\ Institute of Biology and Soils, Russian Academy of Sciences Far Eastern Branch, 159 One Hundred Years of Vladivostok Street, Vladivostok, Russia 690022. \\ *Author for correspondence; email: jslaght@wcs.org.}

Received 6 November 2014; revision accepted 30 March 2015; Published online 28 September 2015 